\title{
Effect of time of initial grazing date and subsequent stocking rate on pasture production and dairy cow performance
}

\author{
Michael O’Donovan ${ }^{\mathrm{a} *}$, Luc Delaby $^{\mathrm{b}}$, Jean Louis PeYRAUD ${ }^{\mathrm{b}}$ \\ a Teagasc, Moorepark Production Research Centre, Fermoy, Co. Cork, Ireland \\ b INRA, UMR Production du Lait, 35590 St-Gilles, France
}

(Received 17 November 2003; accepted 8 November 2004)

\begin{abstract}
The objective of this study was to investigate the effects of contrasting first spring grazing dates (GD) and subsequent stocking rate (SR) on milk production performance of dairy cows. In total, 48 autumn calving Holstein cows ( $160 \pm 35$ days in milk) were assigned to one of four ( $\mathrm{n}=$ 12) different grazing treatments. Two swards were created by grazing in March (early grazing; E) or not grazing until April (late grazing; L). Two stocking rates, high $(\mathrm{H})$ and medium (M), were applied across each sward, beginning on April 17th and finishing after 2 grazing rotations on June 20th. Cows grazing at the high and medium stocking rate were stocked at 6.3 and 5.0 cows.ha ${ }^{-1}$ in rotation 1 . In rotation 2 , the stocking rates were 4.6 and 4.0 cows $\cdot \mathrm{ha}^{-1}$ for both high and medium stocking rates, respectively. Daily herbage allowance $(>50 \mathrm{~mm})$ were on average $12.9,15.7,18.2$ and $21.0 \mathrm{~kg} \mathrm{DM} \cdot \mathrm{cow}^{-1}$ for EH, EM, LH and LM in both rotations, respectively. There was a significant interaction between date of first grazing and stocking rate for milk $(P<0.001)$, fat $(P<0.01)$, protein yield $(P<0.001)$ in both rotations and fat corrected milk yield $(P<0.001)$ in rotation 1 . During the first rotation, cows grazing the EM treatment yielded $24.1 \mathrm{~kg}$ of milk, $894 \mathrm{~g}$ fat and $688 \mathrm{~g}$ protein. The difference in milk production (cow per day) between EM and EH treatments was $+3.0 \mathrm{~kg}$ milk, $+86 \mathrm{~g}$ fat and $+91 \mathrm{~g}$ protein in the first rotation whereas the difference between LM and LH treatments was only $+0.9 \mathrm{~kg}$ milk, $+15 \mathrm{~g}$ fat and protein. During the second rotation, the milk production difference between EM and EH (cow per day) increased and reached $+4.0 \mathrm{~kg}$ milk, $+128 \mathrm{~g}$ fat and $+118 \mathrm{~g}$ protein. The production difference between cows grazing the LM and LH treatments was only $+0.9 \mathrm{~kg}$ milk, $+14 \mathrm{~g}$ fat and $30 \mathrm{~g}$ protein, respectively. Stocking rate had no effect on the milk production performance from late grazed swards. Grass offered above $50 \mathrm{~mm}$ had a higher level of grass utilisation (102 vs. $84 \%$ ) with early grazing, these swards had also higher grass quality, which persisted in subsequent rotations. Early grazed swards should be grazed at a medium-stocking rate to obtain high individual milk production performance.
\end{abstract}

dairy cows / spring grazing / stocking rate / turnout

Résumé - Effet de la date du premier pâturage et du chargement ultérieur sur les performances des vaches laitières et la production de la prairie. L'objectif de cette expérience est d'analyser les conséquences de la date du premier pâturage et du chargement ultérieur sur les performances des

* Corresponding author: maodonovan@moorepark.teagasc.ie 
vaches laitières. Quarante huit vaches laitières (vêlage d'automne - $160 \pm 35$ jours de lactation) ont été affectées à l'un des 4 traitements suivants : deux types de prairie ont été créés par la pratique d'un pâturage Précoce en mars (E) ou pas de pâturage jusqu'en avril (L) et deux niveaux de chargement, Moyen (M) ou Haut $(\mathrm{H})$, ont ensuite été appliqués durant le printemps sur les deux types de prairie. L'expérience a débuté le 17 avril pour s'achever le 20 juin, après deux cycles de pâturage. Les niveaux de chargement $\mathrm{H}$ et $\mathrm{M}$ ont été respectivement de 6,3 et 5,0 vaches'ha ${ }^{-1}$ durant le cycle 1 puis de 4,6 et 4,0 vaches $\cdot \mathrm{ha}^{-1}$ au cycle 2 . En moyenne, les quantités d'herbe offerte $(>50 \mathrm{~mm})$ ont été de 12,9 ; 15,$7 ; 18,2$ et $21,0 \mathrm{~kg} \mathrm{MS} \cdot \mathrm{vache}^{-1}$.jour ${ }^{-1}$ pour les traitements EH, EM, LH et LM respectivement. Une interaction significative entre la date de $1^{\mathrm{er}}$ pâturage et le chargement a été mise en évidence sur les quantités produites de lait $(P<0,001)$, de matières grasses $(P<0,01)$ et de protéines $(P<$ $0,001)$ lors des 2 cycles de pâturage, et sur le lait $4 \%(P<0,001)$ lors du cycle 1 . Au cours du $1^{\text {er }}$ cycle, les vaches du traitement EM ont produit $24,1 \mathrm{~kg}$ de lait, 894 et $688 \mathrm{~g}$ de matières grasses et de protéines, soit 3,0 $\mathrm{kg}$ de lait, $86 \mathrm{~g}$ de matières grasses et $91 \mathrm{~g}$ de protéines de plus que celles du traitement EH. Dans le même temps, entre les traitements LM et LH, les écarts ont atteint respectivement $0,9 \mathrm{~kg}$ de lait et $15 \mathrm{~g}$ de matières grasses et protéiques en faveur du lot $\mathrm{LM}$. Au second cycle, les différences, toujours favorables au chargement Moyen, ont été accrues entre EM et EH, avec $4,0 \mathrm{~kg}$ de lait, $128 \mathrm{~g}$ de matières grasses et $118 \mathrm{~g}$ de protéines pour une différence de seulement $0,9 \mathrm{~kg}$ de lait, $14 \mathrm{~g}$ de matières grasses et $30 \mathrm{~g}$ de protéines entre $\mathrm{LM}$ et $\mathrm{LH}$. Ces résultats suggèrent que les niveaux de chargement appliqués n'ont que peu d'effet dans le cas d'un pâturage tardif. Un pâturage précoce au printemps permet une meilleure valorisation de l'herbe offerte à $5 \mathrm{~cm}(102 \mathrm{vs}$. $84 \%$ ) et améliore la qualité de l'herbe offerte lors des cycles suivants. Néanmoins, il nécessite d'appliquer un chargement moins élevé pour obtenir de meilleures performances individuelles.

\section{vaches laitières / mise à l'herbe / chargement / pâturage de printemps}

\section{INTRODUCTION}

Grazed grass can be increased in the overall diet of the dairy cow by allowing cows greater access to grass early in spring. Many studies have shown the improvement in dairy cow performance with this practice $[10,29]$. As well as improving animal performance, early spring grazing can have beneficial effects by increasing grass utilisation, sward quality and simplifying grazing management. But early spring grazing can reduce herbage mass availability in the second and third grazing rotations which reduces the number of grazing days. At high grazing stocking rates or in difficult weather/ soil conditions, early grazing may not be possible and turnout may have to be delayed. Late turnout to grass, can lead to undergrazing of pastures for a variety of reasons, i.e. excessively high pre-grazing herbage mass, low grazing stocking rates or poor grass utilisation conditions.

A number of studies investigated the effects of early grazing on herbage mass production and sward dynamics [7, 8, 23]. Carton et al. [7] showed that early spring grazing (late March) compared to first grazing in mid April reduced total herbage mass production but increased leaf dry matter production in the period up to mid June. Contrary to this, McFeely and MacCarthy [23] found no significant effect of turnout date on herbage production for the period up to mid June. However, the effects of preliminary grazing in spring on animal performance and subsequent sward quality is poorly investigated, the only previous work was completed by Holmes et al. [16].

A number of questions arise with the practice of early grazing. If sward quality is improved with early grazing, is it possible to allocate a lower herbage allowance with an early grazed sward to achieve a similar level of milk yield per cow as a late grazed sward with a higher herbage allowance? Do sward carryover effects with earlier grazed swards persist into later rotations? Furthermore in the context of the dairy system, is milk production per hectare affected by early as compared to late grazing? The current study was undertaken with the objective to examine the effect of contrasting spring grazing date and stocking rate on the 
milk production performance and grazing management of autumn calving dairy cows.

\section{MATERIALS AND METHODS}

\subsection{Treatments and experimental design}

Four grazing treatments were studied. Two first grazing dates and two stocking rates were contrasted. Swards were grazed in March (early grazing; E) or not grazed until April (late grazing; L). In mid April, two stocking rates were imposed across each sward, High (H) and Medium (M).

The experiment took place over a 10 week period from April 17 to June 20 (2003) at the experimental farm of Mejusseaume (INRA, Le Rheu) located in the Rennes Basin in Brittany (France) using 48 cows and a total area of 12.1 ha.

\subsection{Pasture and grazing management}

Perennial ryegrass pastures, which were on average 5 years old (range 2-12 years), were used. The grass cultivar sown in the paddocks was either $c v$. Belfort, Hercules or Ohio. All cultivars were sown as monocultures. There was no clover in the pastures. Approximately half of the total land area was grazed off during March. Non-experimental cows grazed the early grazed paddocks to an average post-grazing rising plate meter height of $3.9 \mathrm{~cm}$. The pasture height for ungrazed paddocks in March was $7.9 \mathrm{~cm}$. Grazing took place only when the animals were liable to cause the least amount of surface damage. During the pre-experimental grazing period the animals were housed by night. In March, the sum of this grazing period equated to 36 cows grazing at a stocking rate of 6 cows $\cdot \mathrm{ha}^{-1}$ for half-day periods for 22 days (which is in total 66 grazing days per hectare).

After the pre-experimental spring grazing, each paddock grazed or not grazed, was subdivided on a proportional basis. The high stocking rate treatments were allocated $45 \%$ of the paddock area while the medium stocking rate treatments were allocated $55 \%$ of the land area, on both grazed and ungrazed paddock areas. The total area assigned to each treatment, was 2.71 and 3.35 ha for the $\mathrm{H}$ and $\mathrm{M}$ stocking rate treatments, respectively. The nitrogen fertilisation was the same for each treatment, $60 \mathrm{~kg}$ nitrogen $\cdot \mathrm{ha}^{-1}$ was applied in the form of ammonium nitrate after each grazing. Initial nitrogen application commenced for each paddock block after grazing in early spring. Since their sowing, the pastures have bi-annually received a basic dressing of 120,220 and $100 \mathrm{~kg} \cdot \mathrm{ha}^{-1}$ of $\mathrm{P}, \mathrm{K}$ and $\mathrm{Mg}$, respectively.

The sward was strip grazed throughout the trial. The front fence was moved once each day after morning milking. A back fence was erected mid-way through the grazing area of each paddock. Water and a mineral block were always available to each grazing herd.

In rotation 1, the stocking rate imposed on the high and medium treatments was 6.3 and 5.0 cows $\cdot$ ha $^{-1}$, respectively. In rotation 2 , the effective stocking rates were reduced to 4.6 and 4.0 cows $\cdot$ ha $^{-1}$, for high and medium stocking rate treatments respectively. The grazing management rules applied during the study are precisely described in Appendix I.

The minimal and maximum temperatures under shade as well as the rainfall were recorded daily at the Le Rheu weather station which was located approximately $1 \mathrm{~km}$ from the experimental plots.

\subsection{Animals}

The 48 experimental cows grazed in a large herd from mid March and were offered restricted amounts of maize silage with $4 \mathrm{~kg}$ concentrate. Seven days before the experiment commenced the 48 cows grazed day and night and were offered $2 \mathrm{~kg} \cdot \mathrm{cow}^{-1} \cdot \mathrm{day}^{-1}$ of a cereal based concentrate that included a mineral supplement. On the day prior to the experiment beginning, concentrate feeding was ceased. The animals were then offered $300 \mathrm{~g} \cdot \mathrm{cow}^{-1} \cdot \mathrm{day}^{-1}$ of a mineral supplement. 
The herd of 48 cows was made up of $25 \%$ primiparous and $75 \%$ multiparous animals. Treatment groups $(n=12)$ were balanced on the basis of the following criteria: parity, stage of lactation (160 days \pm 35 ), milk yield ( $31.8 \mathrm{~kg} \pm 4.1)$, milk fat content (35.6 $\left.\mathrm{g} \cdot \mathrm{kg}^{-1} \pm 5.9\right)$, milk protein content $\left(29.2 \mathrm{~g} \cdot \mathrm{kg}^{-1} \pm 1.6\right)$, body weight $(622 \mathrm{~kg} \pm$ $48.8)$ and body condition score $(2.3 \pm 0.45)$ recorded in the previous 2 weeks (23 March to April 7). Once the groups were assembled, they were randomised to one of the four grazing treatments.

\subsection{Sward and animal measurements}

Herbage mass above $50 \mathrm{~mm}$ was determined in each grazing paddock by cutting either four or six strips $(0.5 \times 10 \mathrm{~m})$ with an Agria motorscythe. Before and after harvesting, ten grass height measurements were recorded on each cut strip using an electronic plate meter [33] with a plastic plate $(30 \times$ $30 \mathrm{~cm}$ and $4.5 \mathrm{~kg} \cdot \mathrm{m}^{-2}$ ) in order to determine the sampled height precisely and to calculate the sward density ( $\left.\mathrm{kg} \mathrm{DM} \cdot \mathrm{cm}^{-1} \cdot \mathrm{ha}^{-1}\right)$. All mown herbage for each strip was collected and bagged. It was then weighed and sampled. Approximately $1.5 \mathrm{~kg}$ herbage samples were then dried in a drying oven for $48 \mathrm{~h}$ at $80{ }^{\circ} \mathrm{C}$ for $\mathrm{DM}$ determination. The sward height was estimated (100 measurements per ha) on each paddock. This sward height multiplied by the mean sward density from the Agria cuts was used to calculate the herbage mass at the paddock level. To estimate herbage mass from ground level, the residual herbage mass after cutting by the Agria mower was measured. In each strip, residual herbage mass was cut with a scissors at ground level in a $0.1 \mathrm{~m}^{2}$ area. After manual removal of soil and roots the samples were weighed and dried in an oven for $48 \mathrm{~h}$ at $80^{\circ} \mathrm{C}$ to determine DM content. Preand post- grazing sward heights were measured each day with a rising plate meter with 30 measurements per treatment randomly taken across the grazed strip. The pre-grazing sward height measured, multiplied by the mean sward density was used to calculate the daily herbage allowance to the herds.
The calculation method specified by Delaby and Peyraud [11] can be applied to assess herbage mass production and herbage removed. Grass production ( $\mathrm{kg} \mathrm{DM} \cdot \mathrm{ha}^{-1}$ ) was calculated with the following equation: [pre-grazing height - previous post-grazing height] $\times$ sward density. Grass growth $\left(\mathrm{kg} \cdot \mathrm{DM}^{-1} \cdot \mathrm{day}^{-1}\right)$ was calculated by dividing the grass production figure by the number of days regrowth. Grass removed $\left(\mathrm{kg} \mathrm{DM} \cdot \mathrm{cow}^{-1} \cdot\right.$ day $^{-1}$ ) was calculated using the following equation: [pre-grazing height - post-grazing height $] \times$ sward density $\times$ area grazed $\cdot$ cow $^{-1} \cdot$ day $^{-1}$. The grazing outcomes (stocking rate, grazing days $\cdot \mathrm{ha}^{-1}$, milk $\cdot \mathrm{ha}^{-1}$ ) were calculated by rotation according to the methodology of Hoden et al. [14].

Milk yield was recorded daily at both morning and evening milkings (07:00 and 17:00 h) using flowmeters (Westfalia). During six consecutive milkings per week, an individual milk sample was taken in order to determine the fat and protein concentration by infrared spectrophotometry (Milkoscan, Foss Electric, DK-3400 Hillerod, Denmark). Animals were weighed one morning per week, after morning milking. Body condition score was measured monthly as described by Agabriel et al. [2].

\subsection{Chemical analyses}

The samples (dried herbage) were ground on a $0.8 \mathrm{~mm}$ screen before chemical analysis. The OM content was determined on herbage samples $(>50 \mathrm{~mm})$ by ashing at $550^{\circ} \mathrm{C}$ for $5 \mathrm{~h}$ and the nitrogen content was obtained by the method of Dumas [1]. The pepsincellulase digestibility of the herbage was assayed according to the procedure described by Aufrère and Demarquilly [3]. NDF and ADF were analysed as described by van Soest et al. [34]. All of the chemical analyses were performed at the Laboratory of Development and Analyses (22440 Ploufragan, France). The nutritive values (UFL and PDI) of the different types of feed were calculated according to the predictive equations of INRA [17]. 
Table I. Main climatic data before and during the experiment compared to the last 10 years average.

\begin{tabular}{lccccccc}
\hline Month & & Jan & Feb & March & April & May & June \\
\hline Rainfall (mm) & 2003 & 77 & 52 & 32 & 11 & 45 & 35 \\
& $1993-2002$ & 84 & 62 & 50 & 66 & 61 & 43 \\
Rain days & 2003 & 14 & 13 & 6 & 5 & 9 & 7 \\
& $1993-2002$ & 16 & 15 & 12 & 15 & 13 & 9 \\
Mean temperature $\left({ }^{\circ} \mathrm{C}\right)$ & 2003 & 4.3 & 5.3 & 10.4 & 11.2 & 13.8 & 19.1 \\
& $1993-2002$ & 6.7 & 7.2 & 8.9 & 10.4 & 14.1 & 17.2 \\
\hline
\end{tabular}

\subsection{Statistical analyses}

All statistical analysis was carried out using SAS [32]. Both the sward parameters, chemical data and performances per hectare ( $n=16$ for cycle 1 and 20 for cycle 2 ) were analysed by using the analysis of variance, with the following model: $Y_{\mathrm{ijk}}=$ mean + $\mathrm{PK}_{\mathrm{i}}+\mathrm{GD}_{\mathrm{j}}+\mathrm{SR}_{\mathrm{k}}+\mathrm{GD}_{\mathrm{j}} \times \mathrm{SR}_{\mathrm{k}}+\mathrm{e}_{\mathrm{ijk}}$, where: $\mathrm{PK}_{\mathrm{i}}=$ paddock effect $(\mathrm{i}=1$ to 5$) ; \mathrm{GD}_{\mathrm{j}}=$ graz $^{-}$ ing date $(\mathrm{j}=1$ or 2$) ; \mathrm{SR}_{\mathrm{k}}=$ stocking rate $(\mathrm{k}=$ 1 or 2); $\mathrm{GD}_{\mathrm{j}} \times \mathrm{SR}_{\mathrm{k}}=$ interaction of grazing date and stocking rate; $\mathrm{e}_{\mathrm{ijk}}=$ error term.

Daily milk yield, milk constituent yield, milk composition and body weight $(n=48)$ was analysed using covariate analysis with the following model: $\mathrm{Y}_{\mathrm{ijk}}=$ mean $+\mathrm{GD}_{\mathrm{i}}+$ $\mathrm{SR}_{\mathrm{j}}+\mathrm{GD}_{\mathrm{i}} \times \mathrm{SR}_{\mathrm{j}}+\mathrm{bX} \mathrm{ijk}+e_{\mathrm{ijk}}$, where: $\mathrm{GD}_{\mathrm{i}}$ $=$ grazing date effect $(\mathrm{i}=1$ or 2$) ; \mathrm{SR}_{\mathrm{j}}=$ stocking rate $(\mathrm{j}=1$ or 2$) ; \mathrm{GD}_{\mathrm{i}} \times \mathrm{SR}_{\mathrm{j}}=$ interaction of grazing date $\times$ stocking rate; $X_{\mathrm{ijk}}$ were the pre-experimental $\mathrm{Y}_{\mathrm{ijk}}$ values and $e_{\mathrm{ijk}}=$ error term.

\section{RESULTS}

Before and during the experiment, the rainfall and the number of rain days were well below the 10-year average (Tab. I). Mean daily temperatures were lower in February, but similar in all other months except June, when very high temperatures were recorded.

The first rotation began on April 17 and lasted 33 days. The mean offered area was $13 \mathrm{~m}^{2}$ larger for the medium stocking rate
Table II. Starting date, grazing duration, area grazed and stocking rates for the high and medium grazing treatments.

\begin{tabular}{lcc}
\hline Stocking rate & High Medium \\
\hline Rotation 1 (17/4 to 19/5 - 33 days) & & \\
Total area grazed (ha) & 1.91 & 2.41 \\
Offered area $\left(\mathrm{m}^{2} \cdot \mathrm{cow}^{-1} \cdot\right.$ day $\left.^{-1}\right)$ & 48 & 61 \\
Stocking rate $\left(\mathrm{cows} \cdot \mathrm{ha}^{-1}\right)$ & 6.3 & 5.0 \\
& & \\
Rotation $2(\mathbf{2 0 / 5}$ to $\mathbf{2 0 / 6} \mathbf{- 3 2}$ days) & & \\
Total area grazed $(\mathrm{ha})$ & 2.71 & 3.35 \\
Offered area $\left(\mathrm{m}^{2} \cdot \mathrm{cow}^{-1} \cdot \mathrm{day}^{-1}\right)$ & 68 & 78 \\
Stocking rate $\left(\mathrm{cows} \cdot \mathrm{ha}^{-1}\right)$ & 4.6 & 4.0
\end{tabular}

High: high stocking rate; Medium: medium stocking rate.

treatments compared to the high stocking rate treatments (Tab. II). On May 19, 0.80 and 0.94 ha were harvested on the $\mathrm{M}$ and $\mathrm{H}$ treatments, respectively. These areas were incorporated in the second rotation, which lasted 32 days. As grass growth was lower during the second rotation, the grazing area was higher. The mean offered area was $10 \mathrm{~m}^{2}$ larger for the medium stocked treatments.

\subsection{Grass growth and grass composition}

Grazing date had no effect on herbage production or grass growth in rotation 1 (Tab. III). In rotation 2, early grazed swards had higher DM production $\left(+199 \mathrm{~kg} \mathrm{DM} \cdot \mathrm{ha}^{-1}\right)$, they 
Table III. Effect of grazing date and stocking rate on herbage production, herbage mass, sward height and density in rotations 1 and 2.

\begin{tabular}{|c|c|c|c|c|c|c|c|c|}
\hline & \multicolumn{4}{|c|}{ Treatments } & \multicolumn{4}{|c|}{ Statistical analysis } \\
\hline & $\mathrm{EH}$ & EM & LH & LM & Rse & GD & SR & $\mathrm{SD} \times \mathrm{SR}$ \\
\hline \multicolumn{9}{|l|}{ Rotation 1} \\
\hline \multicolumn{9}{|l|}{ Herbage production $\left(\mathrm{kg} \mathrm{DM} \cdot \mathrm{ha}^{-1}\right)$} \\
\hline Daily & 66 & 68 & 70 & 58 & 6.3 & NS & NS & + \\
\hline Total & 2904 & 3001 & 3051 & 2584 & 274.1 & NS & NS & + \\
\hline \multicolumn{9}{|c|}{ Pre-grazing herbage mass $\left(\mathrm{kg} \mathrm{DM} \cdot \mathrm{ha}^{-1}\right)$} \\
\hline$>50 \mathrm{~mm}$ & 2567 & 2627 & 4026 & 3602 & 372.7 & $* * *$ & NS & NS \\
\hline Between $50 \mathrm{~mm}$ and ground level & 3387 & 3478 & 2979 & 3254 & 410.9 & NS & NS & NS \\
\hline$>$ Ground level & 5954 & 6105 & 7004 & 6856 & 649.1 & * & NS & NS \\
\hline Pre-grazing sward height $(\mathrm{cm})$ & 12.7 & 12.2 & 17.6 & 15.9 & 0.98 & $* * *$ & * & NS \\
\hline \multicolumn{9}{|l|}{ Sward density $\left(\mathrm{kg} \mathrm{DM} \cdot \mathrm{cm}^{-1} \cdot \mathrm{ha}^{-1}\right)$} \\
\hline$>50 \mathrm{~mm}$ & 336 & 365 & 321 & 331 & 17.2 & $* *$ & $*$ & NS \\
\hline$>$ Ground level & 677 & 696 & 596 & 651 & 82.2 & NS & NS & NS \\
\hline \multicolumn{9}{|l|}{ Rotation 2} \\
\hline \multicolumn{9}{|l|}{ Herbage production $\left(\mathrm{kg}\right.$ DM·ha $\left.{ }^{-1}\right)$} \\
\hline Daily & 66 & 65 & 60 & 58 & 6.1 & * & NS & NS \\
\hline Total & 2075 & 2029 & 1877 & 1829 & 190.0 & * & NS & NS \\
\hline \multicolumn{9}{|c|}{ Pre-grazing herbage mass $\left(\mathrm{kg} \mathrm{DM} \cdot \mathrm{ha}^{-1}\right)$} \\
\hline$>50 \mathrm{~mm}$ & 2074 & 2117 & 2608 & 2613 & 248.7 & $* * *$ & NS & NS \\
\hline Between $50 \mathrm{~mm}$ and ground level & 4034 & 4103 & 3997 & 4154 & 401.9 & NS & NS & NS \\
\hline$>$ Ground level & 6108 & 6220 & 6605 & 6767 & 535.1 & $*$ & NS & NS \\
\hline Pre-grazing sward height $(\mathrm{cm})$ & 11.8 & 11.5 & 12.9 & 12.9 & 0.83 & $* * *$ & NS & NS \\
\hline \multicolumn{9}{|l|}{ Sward density $\left(\mathrm{kg} \mathrm{DM} \cdot \mathrm{ha}^{-1} \cdot \mathrm{cm}^{-1}\right)$} \\
\hline$>50 \mathrm{~mm}$ & 302 & 320 & 331 & 330 & 25.2 & NS & NS & NS \\
\hline$>$ Ground level & 807 & 821 & 799 & 831 & 80.4 & NS & NS & NS \\
\hline
\end{tabular}

EH: early grazed, high stocking rate; EM: early grazed, medium stocking rate;

LH: late grazed, high stocking rate; LM: late grazed, medium stocking rate;

Rse: residual standard error; GD: grazing date; SR: stocking rate;

NS: not significant; $+: P<0.10 ; *: P<0.05$; **: $P<0.01$; ***: $P<0.001$.

also had higher daily grass growth $(+7 \mathrm{~kg}$ $\mathrm{DM} \cdot \mathrm{ha}^{-1} \cdot$ day $\left.^{-1}\right)$. Early grazed swards had significantly lower pre-grazing herbage mass above $50 \mathrm{~mm}$ and above ground level and had significantly lower pre-grazing height in both rotations compared to late grazed swards. The reduction in HM was about $1000 \mathrm{~kg} \mathrm{DM} \cdot \mathrm{ha}^{-1}(-32 \%)$ in rotation 1 and $500 \mathrm{~kg} \mathrm{DM} \cdot \mathrm{ha}^{-1}(-20 \%)$ in rotation 2 . Sward density increased in rotation 1 with early grazed swards having significantly higher density $\left(+24.6 \mathrm{~kg} \mathrm{DM} \cdot \mathrm{cm}^{-1} \cdot \mathrm{ha}^{-1}\right)$.
Stocking rate was not applied before rotation 1 and so had no effect on herbage production and pre-grazing herbage mass in rotation 1. It tended to have a slight effect on pre-grazing sward height and sward density. This may have been due to two paddock's reduced grass growth and DM production in the LM treatment. In rotation 2, stocking rate had no effect on herbage production, pre-grazing herbage mass, pregrazing herbage height and sward density (Tab. III). 
Table IV. Effect of grazing date and stocking rate on herbage chemical composition $\left(\mathrm{g} \cdot \mathrm{kg}^{-1} \mathrm{DM}\right)$ and nutritive values in rotations 1 and 2 .

\begin{tabular}{|c|c|c|c|c|c|c|c|c|}
\hline & \multicolumn{4}{|c|}{ Treatments } & \multicolumn{4}{|c|}{ Statistical analysis } \\
\hline & $\mathrm{EH}$ & EM & $\mathrm{LH}$ & $\mathrm{LM}$ & Rse & GD & SR & $\mathrm{GD} \times \mathrm{SR}$ \\
\hline \multicolumn{9}{|l|}{ Rotation 1} \\
\hline Dry matter $(\%)$ & 18.4 & 19.0 & 20.6 & 22.4 & 0.74 & $* * *$ & $* *$ & NS \\
\hline Ash & 93 & 96 & 103 & 107 & 10.4 & + & NS & NS \\
\hline Crude protein & 163 & 160 & 150 & 146 & 10.8 & $*$ & NS & NS \\
\hline Crude fibre & 194 & 189 & 213 & 202 & 4.9 & $* * *$ & $* *$ & NS \\
\hline Neutral detergent fibre & 446 & 438 & 486 & 464 & 16.1 & $* * *$ & + & NS \\
\hline Acid detergent fibre & 198 & 193 & 221 & 212 & 4.7 & $* * *$ & $* *$ & NS \\
\hline OM digestibility ${ }^{1}$ & 82.3 & 82.6 & 78.3 & 78.7 & 1.11 & $* * *$ & NS & NS \\
\hline UFL & 1.05 & 1.05 & 0.97 & 0.97 & 0.024 & $* * *$ & NS & NS \\
\hline PDIE & 99 & 98 & 92 & 91 & 2.3 & $* * *$ & NS & NS \\
\hline PDIN & 102 & 101 & 94 & 92 & 6.8 & $*$ & NS & NS \\
\hline \multicolumn{9}{|l|}{ Rotation 2} \\
\hline Dry matter (\%) & 16.7 & 17.5 & 18.3 & 19.6 & 1.04 & $* * *$ & $*$ & NS \\
\hline Ash & 100 & 90 & 95 & 93 & 10.4 & NS & NS & NS \\
\hline Crude protein & 190 & 180 & 172 & 173 & 9.9 & $* *$ & NS & NS \\
\hline Crude fibre & 235 & 236 & 241 & 243 & 10.4 & NS & NS & NS \\
\hline Neutral detergent fibre & 536 & 529 & 553 & 553 & 15.3 & $* *$ & NS & NS \\
\hline Acid detergent fibre & 237 & 237 & 250 & 250 & 11.0 & $*$ & NS & NS \\
\hline OM digestibility ${ }^{1}$ & 77.7 & 77.4 & 74.5 & 73.5 & 1.23 & $* * *$ & NS & NS \\
\hline UFL & 0.96 & 0.96 & 0.91 & 0.90 & 0.026 & $* * *$ & NS & NS \\
\hline PDIE & 100 & 99 & 94 & 94 & 2.2 & $* * *$ & NS & NS \\
\hline PDIN & 119 & 113 & 108 & 109 & 6.2 & ** & NS & NS \\
\hline
\end{tabular}

Abbreviations as in Table III.

UFL: net energy unit for lactation $(1 \mathrm{UFL}=1700 \mathrm{kcal}$ NEL $)$; PDIE and PDIN: protein truly digestible in the intestine $\left(\mathrm{g} \cdot \mathrm{kg}^{-1} \mathrm{DM}\right)$.

${ }^{1}$ Calculated from pepsin-cellulase digestibility [3].

Grazing date had similar effects on herbage chemical composition and nutritive value in both rotations and for both stocking rates (Tab. IV). Early grazed swards had lower $\mathrm{DM}(-2.3 \%)$ and $\operatorname{ADF}\left(-17 \mathrm{~g} \cdot \mathrm{kg}^{-1}\right)$ content but higher crude protein content $\left(+13 \mathrm{~g} \cdot \mathrm{kg}^{-1}\right)$ compared to late grazed swards. Early grazed swards had significantly lower ash $\left(-10.5 \mathrm{~g} \cdot \mathrm{kg}^{-1}\right)$ and crude fibre $\left(-16 \mathrm{~g} \cdot \mathrm{kg}^{-1}\right)$ content in rotation 1 . The difference failed to be significant in rotation 2 . As a consequence early grazed swards had higher UFL $(+0.07)$ and protein values (+6 g PDIE). Stocking rate had a limited effect on herb- age chemical composition. Swards grazed at high stocking rates, for both grazing dates and rotations had lower DM $(-1.1 \%)$ and a higher crude fibre $\left(+8 \mathrm{~g} \cdot \mathrm{kg}^{-1}\right), \mathrm{ADF}$ $\left(+7 \mathrm{~g} \cdot \mathrm{kg}^{-1}\right)$ content was higher only in rotation 1 .

\subsection{Herbage allowance and utilisation}

There was no interaction between grazing date and stocking rate on herbage allowance and herbage utilisation. Herbage allowance was significantly affected by grazing date $(P<0.001)$ and stocking rate $(P<0.001)$ 
Table V. Effect of grazing date and stocking rate and their interaction on herbage allowance and utilisation in rotations 1 and 2 .

\begin{tabular}{|c|c|c|c|c|c|c|c|c|}
\hline & \multicolumn{4}{|c|}{ Treatments } & \multicolumn{4}{|c|}{ Statistical analysis } \\
\hline & EH & EM & LH & LM & Rse & GD & SR & $\mathrm{GD} \times \mathrm{SR}$ \\
\hline \multicolumn{9}{|l|}{ Rotation 1} \\
\hline \multicolumn{9}{|l|}{ 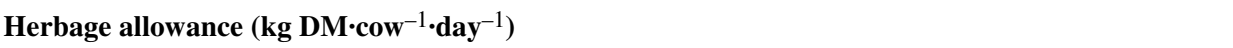 } \\
\hline$>50 \mathrm{~mm}$ & 12.2 & 15.3 & 19.7 & 22.5 & 1.39 & $* * *$ & $* * *$ & NS \\
\hline$>$ Ground level & 28.6 & 35.9 & 34.6 & 43.1 & 2.82 & $* * *$ & $* * *$ & NS \\
\hline \multicolumn{9}{|l|}{ Herbage utilisation } \\
\hline Post grazing sward height $(\mathrm{cm})$ & 4.5 & 4.9 & 7.0 & 7.2 & 0.38 & $* * *$ & NS & NS \\
\hline Grass removed $\left(\mathrm{kg}\right.$ DM$\left.\cdot \mathrm{cow}^{-1} \cdot \mathrm{day}^{-1}\right)$ & 13.0 & 15.6 & 16.5 & 17.9 & 1.14 & $* * *$ & $* * *$ & NS \\
\hline Grazing days (days $\cdot \mathrm{ha}^{-1}$ ) & 210 & 172 & 204 & 158 & 12.9 & NS & $* * *$ & NS \\
\hline Grass removed $\left(\mathrm{kg} \mathrm{DM} \cdot \mathrm{ha}^{-1}\right)$ & 2734 & 2675 & 3384 & 2878 & 323.8 & $*$ & NS & NS \\
\hline \multicolumn{9}{|l|}{ Rotation 2} \\
\hline \multicolumn{9}{|l|}{ Herbage allowance $\left(\mathrm{kg} \mathrm{DM} \cdot \mathrm{cow}^{-1} \cdot \mathrm{day}^{-1}\right)$} \\
\hline$>50 \mathrm{~mm}$ & 13.4 & 16.0 & 17.6 & 20.4 & 1.63 & $* * *$ & $* * *$ & NS \\
\hline$>$ Ground level & 40.6 & 48.6 & 45.6 & 53.8 & 3.61 & $* * *$ & $* * *$ & NS \\
\hline \multicolumn{9}{|l|}{ Herbage utilisation } \\
\hline Post grazing sward height $(\mathrm{cm})$ & 4.8 & 5.2 & 6.1 & 6.4 & 0.42 & $* * *$ & + & NS \\
\hline Grass removed $\left(\mathrm{kg}\right.$ DM$\left.\cdot \mathrm{cow}^{-1} \cdot \mathrm{day}^{-1}\right)$ & 13.9 & 15.6 & 15.3 & 16.8 & 1.04 & $* *$ & $* * *$ & NS \\
\hline Grazing days $\left(\right.$ days $\left.\cdot \mathrm{ha}^{-1}\right)$ & 151 & 129 & 146 & 126 & 8.4 & NS & $* * *$ & NS \\
\hline Grass removed $\left(\mathrm{kg} \mathrm{DM} \cdot \mathrm{ha}^{-1}\right)$ & 2133 & 2055 & 2258 & 2167 & 141.8 & + & NS & NS \\
\hline
\end{tabular}

Abbreviations as in Tables II and III.

in both rotations (Tab. V). Herbage allowance allocated above $50 \mathrm{~mm}$ was on average 12.8 , 15.7, 18.7 and $21.5 \mathrm{~kg} \mathrm{DM} \cdot \mathrm{ha}^{-1} \cdot \mathrm{cow}^{-1} \cdot$ day $^{-1}$ for EH, EM, LH and LM grazing treatments, respectively. Herbage allowance at ground level was the lowest for EH treatment, intermediate and similar for EM and LH treatment (42.2 and 40.1 DM.cow ${ }^{-1} \cdot$ day $\left.^{-1}\right)$ and the highest for the LM treatment. In all treatments, herbage allowance at ground level was higher in rotation 2 than in rotation 1.

Post-grazing sward height was on average $1.9 \mathrm{~cm}$ lower for early grazed swards compared to late grazed swards in both rotations (Tab. V). Higher stocked swards tended to have lower post-grazing heights than medium stocked swards ( $0.4 \mathrm{~cm}$ on average). Cows grazing the early swards removed less herbage than cows grazing the late grazed swards $\left(-2.1 \mathrm{~kg} \mathrm{DM} \cdot \mathrm{cow}^{-1} \cdot \mathrm{day}^{-1}\right)$. For the high stocking rate treatment, the quantity of herbage removed was lower compared with the medium stocking rate treatment $(-1.9 \mathrm{~kg}$ $\left.\mathrm{DM} \cdot \mathrm{cow}^{-1} \cdot \mathrm{day}^{-1}\right)$.

Early grazed swards had significantly lower grass removed than late grazed swards $-426 \mathrm{~kg} \mathrm{DM} \cdot \mathrm{ha}^{-1}$ in rotation 1 and $-199 \mathrm{~kg} \mathrm{DM} \cdot \mathrm{ha}^{-1}$ in rotation 2 , respectively. Higher stocked swards achieved more grazing days per ha $(+42$ and +20 in rotations 1 and 2 , respectively) but failed to increase the amount of grass removed per hectare.

\subsection{Animal performance}

In rotation 1 , early grazing associated with a high stocking rate had a significant 
Table VI. Effect of grazing date and stocking rate on milk yield, milk composition, bodyweight and body condition score of grazing dairy cows.

\begin{tabular}{|c|c|c|c|c|c|c|c|c|}
\hline & \multicolumn{4}{|c|}{ Treatments } & \multicolumn{4}{|c|}{ Statistical analysis } \\
\hline & EH & EM & LH & LM & Rse & GD & SR & $\mathrm{GD} \times \mathrm{SR}$ \\
\hline \multicolumn{9}{|l|}{ Rotation 1} \\
\hline Milk yield $\left(\mathrm{kg} \cdot \mathrm{day}^{-1}\right)$ & 21.1 & 24.1 & 23.8 & 24.8 & 1.17 & $* * *$ & $* * *$ & $* * *$ \\
\hline Milk fat yield $\left(\mathrm{g} \cdot \mathrm{day}^{-1}\right)$ & 808 & 894 & 896 & 910 & 50.9 & $* * *$ & $* * *$ & $* *$ \\
\hline Milk protein yield $\left(\mathrm{g} \cdot\right.$ day $\left.^{-1}\right)$ & 597 & 688 & 692 & 707 & 35.3 & $* * *$ & $* * *$ & $* * *$ \\
\hline $4 \%$ FCM yield $\left(\mathrm{kg} \cdot\right.$ day $\left.^{-1}\right)$ & 20.6 & 23.0 & 23.0 & 23.5 & 1.07 & $* * *$ & $* * *$ & $* * *$ \\
\hline Milk fat content $\left(\mathrm{g} \cdot \mathrm{kg}^{-1}\right)$ & 38.5 & 37.1 & 37.6 & 36.9 & 1.88 & NS & + & NS \\
\hline Milk protein content $\left(\mathrm{g} \cdot \mathrm{kg}^{-1}\right)$ & 28.4 & 28.6 & 29.1 & 28.6 & 0.80 & NS & NS & NS \\
\hline Body weight (kg) & 592 & 593 & 602 & 596 & 11.1 & $*$ & NS & NS \\
\hline Milk output per ha & 4351 & 4207 & 4852 & 3927 & 250.0 & NS & $* *$ & $*$ \\
\hline \multicolumn{9}{|l|}{ Rotation 2} \\
\hline Milk yield $\left(\mathrm{kg} \cdot \mathrm{day}^{-1}\right)$ & 18.2 & 22.2 & 20.3 & 21.2 & 2.10 & NS & $* * *$ & $* * *$ \\
\hline Milk fat yield $\left(\mathrm{g} \cdot\right.$ day $\left.^{-1}\right)$ & 691 & 819 & 768 & 782 & 80.5 & NS & $* * *$ & $* *$ \\
\hline Milk protein yield $\left(\mathrm{g} \cdot \mathrm{day}^{-1}\right)$ & 530 & 648 & 592 & 622 & 59.2 & NS & $* * *$ & $* * *$ \\
\hline 4\% FCM yield $\left(\mathrm{kg} \cdot \mathrm{day}^{-1}\right)$ & 17.7 & 21.2 & 19.6 & 20.2 & 1.92 & NS & $* * *$ & NS \\
\hline Milk fat content $\left(\mathrm{g} \cdot \mathrm{kg}^{-1}\right)$ & 38.1 & 37.0 & 38.0 & 37.0 & 2.40 & NS & NS & NS \\
\hline Milk protein content $\left(\mathrm{g} \cdot \mathrm{kg}^{-1}\right)$ & 29.3 & 29.2 & 29.3 & 29.4 & 1.17 & NS & NS & NS \\
\hline Body weight $(\mathrm{kg})$ & 589 & 581 & 590 & 594 & 17.8 & NS & NS & NS \\
\hline Milk output per ha & 2692 & 2890 & 2940 & 2655 & 118.4 & NS & NS & $* * *$ \\
\hline
\end{tabular}

Abbreviations as in Tables II and III; FCM: fat corrected milk yield.

negative effect $(P<0.001)$ on milk, fat, protein and FCM yield (Tab. VI). The three other treatments did not differ significantly. In rotation 2, the negative effect of grazing date disappeared because milk production increased with the EM treatment compared to the two late grazing treatments. Consequently, the interaction between treatment and stocking rate persisted. The effects of stocking rate and grazing date on milk composition in both rotations were small. Cows grazing the late grazed swards had higher bodyweight $(+8 \mathrm{~kg}, P<0.05)$ than cows grazing the earlier grazed swards in rotation 1. Body condition score was not affected by either of the main factors. High stocking rate increased milk output per ha $\left(+535 \mathrm{~kg} \cdot \mathrm{ha}^{-1}\right)$ only in rotation 1 , but the interaction with grazing date was significant in each rotation.

\section{DISCUSSION}

The main objective of this study was to investigate the effect of different first spring grazing dates and stocking rates on milk production performance and grazing management of dairy cows. By virtue of this objective the main variables need to be examined over an extended time period since the effect of different turnout dates has been shown to affect grass supply well into the grazing season. However this effect combined with stocking rate may have larger effects on the output per unit of land area. 


\subsection{Grass production and grass quality}

The results from the present study suggest that early spring grazing does not reduce the sward's growth potential, as there was no difference in grass growth rates between the different grazing dates. The same difference $(4 \mathrm{~cm})$ in sward height which was created in late March after the grazing off period was present during rotation 1. During the second rotation, grass growth was $5 \mathrm{~kg} \mathrm{DM} \cdot \mathrm{ha}^{-1} \cdot \mathrm{day}^{-1}$ higher with the early grazing treatment even though the post-grazing height in rotation 1 was lower for these treatments. This shows the capacity of early grazed swards to achieve similar grass growth rates as non-grazed swards. This agrees with Cowling [9] and Binnie et al. [5] who found that an early initial defoliation leaving the apical meristems intact increased annual DM production. In contrast to this finding, McFeely and MacCarthy [23] reported that time of initial grazing had no significant effect on total DM production up until mid June. Carton et al. [7], Roche et al. [28] and Johnson and Parsons [18] all reported a reduction in DM yield because of early turnout. Late turnout can lead to large accumulations of herbage which can be difficult to graze [20,35]. High post-grazing sward heights reduce the efficiency of grass utilisation, which also reduces sward productivity. Brereton and Carton [6] have shown that the rate of dry matter production in the upper harvested horizon of a high stubble sward was lower than the rate in short stubble swards. The reduction in pre-grazing herbage mass above $50 \mathrm{~mm}$ as a result of the early turnout treatment was large and averaged $1217 \mathrm{~kg}$ $\mathrm{DM} \cdot \mathrm{ha}^{-1}$ in rotation 1 . This figure fits well with the amount of DM per ha grazed off in March (i.e. $1230 \mathrm{~kg} \mathrm{DM} \cdot \mathrm{ha}^{-1}$ ), assuming the same sward density in March as in rotation $1\left(300 \mathrm{~kg} \mathrm{DM} \cdot \mathrm{ha}^{-1}\right)$. The herbage mass available to the early grazed treatments was reduced in rotation 1 , the cows grazed to low post-grazing sward heights, which, in turn, decreased the pre-grazing herbage mass further for these treatments in rota- tion $2\left(-516 \mathrm{~kg} \mathrm{DM} \cdot \mathrm{ha}^{-1}\right)$ compared to the late grazed treatments.

Herbage from the early grazed swards was of higher quality (increased OMD and UFL value) relative to the late grazed swards. That in part reflects seasonal trends in the accumulation of dead herbage [22] and possibly a positive change in the green leaf proportion. By delaying spring grazing, dead herbage is allowed to build up at the base of the sward because of increased tiller death rate [8]. The problem of high senescence rates is further increased if the swards are not grazed to low post-grazing sward heights. Carton et al. [8] found a positive correlation between post-grazing sward height and leaf senescence rates. Swards with high levels of senescence may be carried over from rotation to rotation if not grazed to the correct height. The quality of grass intake declines as the dead material in a sward increases [27].

\subsection{Animal performance and grass utilisation}

In rotational grazing systems, a decline in milk production per cow is classically found with increasing stocking rate corresponding to a decrease of herbage allowance $[15,19,24]$. Limiting factors concerning herbage allowance and its effect on herbage intake and milk production are the height of the residue left post-grazing $[12,21]$. Beneficial effects of increased grazing pressure in springtime on subsequent pasture quality and milk yield have been recorded in other trials $[4,25,30,31]$. Our results showed that herbage allowance and grass quality interact to determine animal performance.

In this study even though grass allowance above $50 \mathrm{~mm}$ was lower for the cows grazing the EM treatment, they produced as much milk as the two later grazed treatments while achieving higher grass utilisation ( $>100 \%$ vs. $84 \%$, respectively). It is clear that the sward structure presented to 
the cows affected their performance. Later grazed swards were of poorer quality as confirmed by the chemical analysis and nutritive value of herbage offered. The reduced milk yield with poorer quality swards compared to EM, despite higher daily herbage allowance (DHA) above $50 \mathrm{~mm}$ and postgrazing height, emphasises clearly the conditioning effect of early turnout on sward structure. Stakelum and Dillon [31]; Holmes et al. [16] concluded, that higher milk performance was achieved by animals consuming higher quality herbage from lower herbage mass swards. A lower grass allowance above $50 \mathrm{~mm}$ can be tolerated with early grazed swards, and will have beneficial effects on milk production performance.

The cows grazing the early grazed swards recorded lower post-grazing heights than the late grazed swards, because of lower pregrazing heights combined with the reduced grass allowance. Post-grazing height was similar for the two early grazing treatments. It is possible that EH cows, offered the lower herbage allowance, were physically restricted to grazing further into the sward. This resulted in a reduction in milk yield compared to EM cows. Cows grazing the late turnout treatments grazed to the same post-grazing height. While these animals had a higher grass allowance above $50 \mathrm{~mm}$, they were near the upper limit of grass allowance for this sward type and may not graze any further. Delagarde et al. [13] reported similar findings to this. Consequently, there was no difference in milk, fat and protein production between the two stocking rates on the late turnout treatments.

The benefit of increased sward quality is illustrated by the UFL removed (grass removed $x$ grass UFL value) by the cows grazing the EM sward in rotation 1 which had similar UFL removed and milk production as the cows grazing the LH sward. However in rotation 2, cows grazing the EM swards had higher UFL removed than the cows grazing the LH sward and hence had higher milk production performance. This result clearly shows the benefit of early spring grazing on improving sward quality.

The difference in grass removed between the two early grazed treatments was large and was on average $2.2 \mathrm{~kg} \mathrm{DM} \cdot \mathrm{cow}^{-1}$. day ${ }^{-1}$ across both rotations. The response in milk yield per $\mathrm{kg}$ grass removed was $1.2 \mathrm{~kg}$ (rotation 1) and $2.4 \mathrm{~kg}$ (rotation 2). Therefore the response to the extra DM allocated was large, agreeing with the findings of Peyraud et al. [26]. Cows grazing the LM swards had higher herbage allowance than cows grazing LH swards, but the milk production difference was small $1.0 \mathrm{~kg}$ (rotation 1) and $0.9 \mathrm{~kg}$ (rotation 2). Therefore, at high herbage masses, increasing herbage allowance did not increase milk production. The quantity of grass removed was on average $+1.5 \mathrm{~kg}$ $\mathrm{DM} \cdot \mathrm{cow}^{-1} \cdot \mathrm{day}^{-1}$ higher for the LM animals. The response to the extra DM offered was lower than the previous relationship $0.7 \mathrm{~kg}$ milk $\cdot \mathrm{kg}^{-1}$ grass removed (rotation 1) and $0.6 \mathrm{~kg}$ (rotation 2). When considering DHA above $50 \mathrm{~mm}$, Peyraud et al. [26] observed on vegetative perennial ryegrass swards an increase in dry matter intake $\left(+0.05 \mathrm{~kg} \mathrm{DM} \cdot \mathrm{day}^{-1}\right)$ as DHA increases above $20 \mathrm{~kg}$ DM·day ${ }^{-1}$. With late grazed swards, allowing high grass allowance maybe wasteful as the gain in milk production is low.

During the two rotations, the number of grazing days per hectare was not affected by grazing date but, as expected, was increased with the high stocking rate. With the late grazed sward, the use of a medium stocking rate reduced milk output per ha especially in the first rotation as a direct consequence of the reduced number of grazing days. With the early grazed sward, the lower milk production per cow per day on the EH treatment diluted the stocking rate effect as the grazing season evolved. Nevertheless, it should be pointed out that the early grazing date allowed 66 days $\cdot$ ha $^{-1}$ in March and thus the total grazing days per hectare between March and June were similar for the EM and LH treatments. 


\section{CONCLUSION}

The production of grass for early grazing has particular importance for grass-based systems of milk production. How this grass is used has major effects on milk production per cow and per ha. Therefore delaying grazing in spring will result in high herbage mass swards which can support higher stocking rates. Milk production per hectare will be increased at least in the short term. In the long term this study shows the benefit of earlier grazing on milk production and sward dynamics. As well as producing milk of higher value (increased milk and fat corrected milk yield) the dairy farmer is mak- ing efficient use of a low cost feed. Early spring grazing can act as a sward conditioner, i.e. to avoid the build up of excessively high pre-grazing yields, it can also simplify grazing management. The high level of milk performance achieved by the cows grazing the EM treatment even with lower grass allowance than the LH and LM treatments clearly shows the benefits of early grazing on sward structure and sward quality. Therefore if the land area available and soil type allow, the practice of early grazing is recommended as it has beneficial effects on cow performance and sward quality when performed at a medium stocking rate.

Appendix I. Methodology used to define stocking rate according to the herbage mass present.

In this study, the high stocking rate was defined with the objective of maintaining a herbage allowance of $18 \mathrm{~kg} \mathrm{DM} \cdot \mathrm{day}^{-1}$ for the cows grazing the LH treatment. The difference in stocking rate between high and medium was calculated to obtain a similar herbage allowance (> ground level) for the $\mathrm{LH}$ and EM treatment.

Consequently, the daily allocated grazing area was based on the four following rules: (i) Daily grazing area for $\mathrm{LH}$ treatment was calculated to offer $18 \mathrm{~kg} \mathrm{DM} \cdot \mathrm{cow}^{-1} \cdot \mathrm{day}^{-1}$ (>50 mm).

(ii) The same grazing area per cow per day was allocated to the LH and EH treatments.

(iii) The daily grazing area for EM was calculated to offer the same DMpercow perday from ground level as the $\mathrm{LH}$ treatment.

(iv) The same grazing area was offered to the LM and EM grazing treatments.

Example of the calculation of the stocking rate according to the herbage mass and grazing rules applied.

\begin{tabular}{lcccc}
\hline Grazing date & Early & Early & Late & Late \\
Stocking rate & High & Medium & High & Medium \\
Herbage mass $>$ 50 $\mathrm{mm}\left(\mathrm{kg} \mathrm{DM} \cdot \mathrm{ha}^{-1}\right)$ & 1500 & 1500 & 2500 & 2500 \\
Herbage mass $>$ ground level $\left(\mathrm{kg} \mathrm{DM} \cdot \mathrm{ha}^{-1}\right)$ & 3500 & 3500 & 4500 & 4500 \\
Herbage allowance $>50 \mathrm{~mm}\left(\mathrm{~kg} \mathrm{DM} \cdot \mathrm{cow}^{-1} \cdot \mathrm{day}^{-1}\right)$ & 10.8 & 13.9 & 18.0 & 23.1 \\
Area $\left(\mathrm{m}^{2} \cdot \mathrm{cow}^{-1} \cdot \mathrm{day}^{-1}\right)$ & 72.0 & 92.6 & 72.0 & 92.6 \\
Herbage allowance $>$ ground level $\left(\mathrm{kg} \mathrm{DM} \cdot \mathrm{cow}^{-1} \cdot \mathrm{day}^{-1}\right)$ & 25.2 & $\mathbf{3 2 . 4}$ & $\mathbf{3 2 . 4}$ & 41.7 \\
Stocking rate $^{1}$ & 5.5 & 4.3 & 5.5 & 4.3 \\
\hline
\end{tabular}

${ }^{1}$ For a 25 day rotation. 


\section{ACKNOWLEDGEMENTS}

The authors thank all the staff of the Mejusseaume farm for their skilled technical input with the grazing management and measurements during the study.

\section{REFERENCES}

[1] AFNOR, Aliments des animaux, Association Française de Normalisation, Paris, France, 1985 .

[2] Agabriel J., Giraud J.M., Petit M., Détermination et utilisation de la note d'état d'engraissement en élevage allaitant, Bull. Tech. CRZV Theix 66 (1986) 43-50.

[3] Aufrère J., Demarquilly C., Predicting organic matter digestibility of forage by two pepsincellulase methods, Proc. of the 16th Int. Grassl. Congr., Nice, France, 1989, pp. 877878.

[4] Baker A.M.C., Leaver J.D., Effect of stocking rate in early season on dairy cow performance and sward characteristics, Grass Forage Sci. 41 (1986) 333-340.

[5] Binnie R.C., Chestnutt D.M.B., Murdoch J.C., The effect of time of initial defoliation and height of defoliation on the productivity of perennial ryegrass swards, Grass Forage Sci. 35 (1980) 267-273.

[6] Brereton A.J., Carton O.T., Analysis of the seasonal changes in the structure of a perennial ryegrass (Lolium perenne $L$.) sward under different managements, Irish J. Agr. Res. 25 (1986) 97-110.

[7] Carton O.T., Brereton A.J., O'Keeffe W.F., Keane G.P., Effect of turnout date and grazing severity in a rotationally grazed sward in spring, 1. Dry matter production, Irish J. Agr. Res. 28 (1989) 153-163.

[8] Carton O.T., Brereton A.J., O'Keeffe W.F., Keane G.P., Effect of turnout date and grazing severity in a rotationally grazed sward in spring, 1. Tissue Turnover, Irish J. Agr. Res. 28 (1989) 165-175.

[9] Cowling D.W., The effect of the early application of nitrogenous fertiliser and of the time of cutting in spring on the yield of ryegrass/ white clover swards, J. Agr. Sci. 66 (1966) 413.

[10] Dillon P., Crosse S., O’Brien B., Mayes B., The effect of forage type and concentrate supplementation level on the performance of spring calving dairy cows in early lactation, Grass Forage Sci. 50 (2002) 212-224.
[11] Delaby L., Peyraud J.L., Effect d'une réduction simultanée de la fertilistion azotée et du chargement sur les performances des vaches laitières et la valorisation du pâturage, Ann. Zootech. 47 (1998) 17-39.

[12] Delagarde R., Peyraud J.L., Parga J., Ribeiro Filho H.M.N., Caractéristiques de la prairie avant et après pâturage : quels indicateurs de l'ingestion chez la vache laitières ? Renc. Rech. Ruminants 8 (2001) 209-212.

[13] Delagarde R., Prache S., D'Hour P., Petit M., Ingestion de l'herbe par les ruminants au pâturage, Fourrages 166 (2001) 189-212.

[14] Hoden A., Micol D., Liénard G., Muller A., Peyraud J.L., Interpretation des essais de pâturage avec des bovins : terminologie, modes de calcul, bilans annuels, Bull. Tech. CRZV Theix 63 (1986) 31-42.

[15] Hoden A., Peyraud J.L., Muller A., Delaby L., Faverdin P., Simplified rotational grazing management of dairy cows: effects of rates of stocking and concentrates, J. Agr. Sci. 116 (1991) 417-428.

[16] Holmes C.W., Hoogendoorn C.J., Ryan M.P., Chu A.C.P., Some effects of herbage composition, as influenced by previous grazing management, on milk production by cows grazing on ryegrass/white clover pastures. 1. Milk production in early spring: effects of different regrowth intervals during the preceding winter period, Grass Forage Sci. 47 (1992) 309315 .

[17] INRA, Alimentation des ruminants : Révision des systèmes et des tables de l'INRA, Bull. Tech. CRZV Theix 70 (1987) 222 p.

[18] Johnson I.R., Parsons A.J., Use of a model to analyse the effects of continuous grazing managements on seasonal patterns of grass production, Grass Forage Sci. 40 (1985) 449458 .

[19] King K.R., Stockdale C.R., The effects of stocking rate and nitrogen fertiliser on the productivity of irrigated perennial pasture grazed by dairy cows. 2. Animal Production, Aust. J. Exp. Agr. An. Husb. 20 (1980) 537-542.

[20] Korte C.J., Watkin B.R., Harris W., Effects of timing and intensity of spring grazings on reproductive development, tillering and herbage production of perennial ryegrass dominant pasture, New Zeal. J. Agr. Res. 27 (1984) 135-149.

[21] Le Du Y.L.P., Combellas J., Hodgson J., Baker R.D., Herbage intake and milk production by grazing dairy cows, 2 . The effects of level of winter feeding and daily herbage allowance, Grass Forage Sci. 34 (1979) 249_ 260. 
[22] L'Huillier P.J., Effect of dairy cattle stocking rate and degree of defoliation on herbage accumulation and quality in ryegrass-white clover pasture, New Zeal. J. Agr. Res. 30 (1987) 149-157.

[23] McFeely P.C., MacCarthy D., Effect of time of initial spring grazing and nitrogen use on pasture production, Irish J. Agr. Res. 20 (1981) 137-146.

[24] McMeekan C.P., Walsh M.J., The inter-relationships of grazing methods and stocking rate on the efficiency of pasture utilisation by dairy cattle, J. Agr. Sci. 61 (1963) 147-166.

[25] Michel P., Fulkerson W.J., Effect of level of utilisation of pasture in spring on pasture composition in summer and on milk production in spring and summer, in: Philips T.I. (Ed.), The Challenge: Efficient Dairy Production, Proc. ASAP-NZAP Dairy Prod. Conf., AlburyWodong, Australia, 1985, pp. 66-67.

[26] Peyraud J.L., Comeron E.A., Wade M.H., Lemaire G., The effect of daily herbage allowance, herbage mass and animal factors upon herbage intake by grazing dairy cows, Ann. Zootech. 45 (1996) 201-217.

[27] Rattray P.V., Clark D.A., Factors affecting the intake of pasture, New Zeal. Agr. Sci. 18 (1984) 141-146.

[28] Roche J.R., Dillon P., Crosse S., Rath M., The effect of closing date of pasture in autumn and turnout date in spring on sward characteristics, dry matter yield and milk production of spring calving dairy cows, Irish J. Agr. Food Res. 35 (1996) 127-140.

[29] Sayers H.J., Mayne C.S., Effect of early turnout to grass in spring on dairy cow performance, Grass Forage Sci. 56 (2001) 259-267.

[30] Stakelum G., Dillon P., The effect of grazing pressure in spring/early summer in rotationally grazed pastures on subsequent (1) Sward Characteristics, Irish J. Agr. Res. (2005) in press.

[31] Stakelum G., Dillon P., The effect of grazing pressure in spring/early summer in rotationally grazed pastures on subsequent (2) Animal performance, Irish J. Agr. Res. (2005) in press.

[32] Statistical Analysis Systems Institute Inc., SAS User's Guide, SAS Institute, Cary, NC, 1987.

[33] Urban B., Caudal J.P., Herbometre automatise, in: INRA Dept. Informatique (Ed.), Les journées de la mesure, Électronique, informatique, automatique, Port Leucate, France, 1990, pp. 57-59.

[34] Van Soest P.J., Robertson J.B., Lewis B.A., Carbohydrate methodology, metabolism and nutrition implications in dairy cattle, J. Dairy Sci. 74 (1991) 3583-3597.

[35] Watkin B.R., Clements R.J., The effects of grazing animals on pastures, in: Wilson J.R. (Ed.), Plants Relations in Pastures, Commonwealth Scientific and Industrial Research Organisation, Melbourne, Australia, 1978, pp. 273-289. 